\title{
Профілактика кровотеч у хворих на гемофілію
}

\author{
І.М. Скрипник', Г.С. Маслова', Ю.О. Гусаченко'ㄹ, Т.В. Лиманець ${ }^{1,2}$ \\ 'Українська медична стоматологічна академія, Полтава, Україна \\ 2Комунальне підприємство «Полтавська обласна клінічна лікарня ім. М.В. Скліфосовського Полтавської обласної ради», Полтава, Україна
}

Анотація. Ведення пацієнтів із тяжкою формою гемофілії А і В залишається складною проблемою клінічної медицини, що зумовлено високою частотою розвитку антитіл проти дефіцитних факторів. Вирішенням питання може бути застосування препаратів із шунтуючим механізмом дії, а саме активованого ептакогу альфа (rFVIla) та антиінгібіторного коагуляційного комплексу факторів згортання крові II, VII, IX, X. Ефективність застосування антиінгібіторного коагуляційного комплексу доведена міжнародними рандомізованими клінічними дослідженнями, відповідно до яких вона становить близько 80\%. Вагомою його перевагою $\epsilon$ тривалий період напіврозпаду - до 8-12 год. Із сучасної точки зору, важливе значення мають принципи застосування антиінгібіторного коагуляційного комплексу з метою превенції епізодів кровотеч. Відповідно до результатів міжнародних рандомізованих клінічних досліджень максимально ефективним $€$ профілактичне його призначення, яке передбачає введення у дозі 80-85 MO/кг маси тіла 3 рази на тиждень.

Ключові слова: профілактика кровотеч, інгібіторна форма гемофілії, шунтуючий механізм дії, антиінгібіторний коагуляційний комплекс.

На сьогодні основним методом лікування та профілактики геморагічних ускладнень у хворих на гемофілію залишається гемостатична замісна факторна терапія, яка реалізується шляхом застосування плазмових та рекомбінантних концентратів факторів згортання крові (ФЗК) та препаратів із шунтуючим механізмом дії [1, 2].

Профілактичне лікування кровотеч у дорослих хворих на гемофілію полягає у внутрішньовенному введенні концентратів ФЗК. Метою профілактики $\epsilon$ переведення тяжкої форми гемофілії у середньотяжку, досягаючи мінімального рівня дефіцитного фактора $>2 \%$, а в деяких випадках - і в легку форму (>5\%) [2]. Це дозволить попередити розвиток гемофільної артропатії, знизити частоту геморагічних епізодів і ризик розвитку тяжких ускладнень. Таким чином, пацієнт отримує можливість відчути свободу дій, впевненість, незалежність від захворювання, що значно покращує якість життя.

Профілактика кровотеч у хворих на гемофілію може бути первинною або вторинною. Первинна профілактика - довготривале лікування хворих із тяжкою формою гемофілії A і B, яка зазвичай починається у віці 1-2 роки до появи клінічних симптомів захворювання і триває щонайменше до закінчення росту кісток. Первинною може називатися профілактика незалежно від віку у хворих, які мають в анамнезі виключно гемартроз. Вторинна профілактика кровотеч показана пацієнтам із тяжкою формою гемофілії після появи $\geq 2$ крововиливів у порожнину суглоба. ІІї проводять з метою зниження темпів розвитку артропатії [3]. Згідно з даними Всесвітньої федерації хворих на гемофілію (World Federation of Hemophilia - WFH) [2] виділяють також третинну профілактику, яку розпочинають вже після розвитку ураження суглобів, які діагностовані при фізикальному огляді та рентгенографії суглобів.

Одним із найтяжчих ускладнень замісної терапії у хворих на гемофілію $€$ розвиток антитіл проти факторів VIII або IX, які блокують їх прокоагулянтну активність, завдяки чому вони отримали назву інгібіторів. Розвиток інгібіторних антитіл до факторів VIII i IX призводить до зростання частоти епізодів тяжких кровотеч, підвищуючи показники інвалідизації і смертності. Антитіла до фактора VIII виявляють значно частіше (10-35\%), ніж до фактора IX (3-5\%). Вони виникають переважно у дитячому віці - 3-6 років [1, 2]. 3 віком ймовірність виникнення інгібіторів значно знижується, проте залишається досить високою за умови лікування хворих на вимогу.

Для забезпечення гемостазу при інгібіторній формі гемофілії А та В застосовують антиінгібіторні препарати з шунтуючим механізмом дії незалежно від титру інгібітора:

- ептаког альфа активований (rFVIla) (рівень доказовості A);

- антиінгібіторний коагуляційний комплекс ФЗК II, VII, IX, X (рівень доказовості A) [1, 3].

Одночасне застосування зазначених препаратів неприпустимо через високий ризик розвитку тромботичних ускладнень (рівень доказовості Е) [3].

Ефективність застосування антиінгібіторного коагуляційного комплексу доведена результатами міжнародних рандомізованих клінічних досліджень, відповідно до яких вона становить близько $80 \%$. Вагомою перевагою цього комплексу $\epsilon$ його тривалий період напіврозпаду - до 8-12 год $[4,5]$.

Відповідно до сучасних рекомендацій, антиінгібіторний коагуляційний комплекс має призначатися пацієнтам із тяжкою формою гемофілії та високим титром інгібіторних антитіл (>5 одиниць Бетезда (БО)/ мл) у постійному режимі, який має перевагу перед лікуванням за вимогою. Так, у рандомізованому мультицентровому клінічному дослідженні NCT00851721 проводили порівняльну оцінку застосування антиінгібіторного коагуляційного комплексу у профілактичному режимі та за потребою під час епізодів кровотеч [6]. Профілактичний режим застосування досліджуваного препарату у пацієнтів із інгібіторною формою гемофілії А і В статистично значущо призводив до редукції кількості епізодів кровотеч порівняно з режимом за вимогою. У дослідження було включено 36 пацієнтів, із них гемофілія А встановлена у 33 (91,7\%), гемофілія В - у 3 (8,3\%). Антиінгібіторний коагуляційний комплекс за потребою отримували 19 , у режимі профілактики 17 пацієнтів. Спостереження пацієнтів тривало 12 міс. Серед хворих на гемофілію A і B, яким вводили комплекс за потребою, загальна середньорічна кількість епізодів кровотеч становила 28,7 (IQR (interquartile range) 32,3), із них спонтанні кровотечі - 18,9 (IQR 32,6), спонтанні крововиливи у суглоби - 16,6 (IQR 30,9). За умови призначення препарату у профілактичному режимі загальна середньорічна частота епізодів кровотеч становила 7,9 (IQR 8,1), із них спонтанні кровоте4і - 5,6 (IQR 5,1), спонтанні крововиливи у суглоби - 4,5 (IQR 5,1). Taким чином, застосування антиінгібіторного коагуляційного комплексу у хворих на інгібіторну форму гемофілії А і В зумовлювало зменшення загальної кількості річних епізодів кровотеч на $72,5 \%$ ( $p=0,0003)$, спонтанних кровотеч на 70,5\% ( $\mathrm{p}=0,0008)$, спонтанних гемартрозів на 73\% $(\mathrm{p}=0,0013)$. За результатами цього дослідження, саме профілактичний режим застосування препарату був ефективним та безпечним щодо редукції кровотеч, в тому числі крововиливів у суглоби, попередження розвитку нових таргетних суглобів у пацієнтів із персистуючим високим титром інгібітора факторів VIII і IX [6].

Нижче наведено приклад високої ефективності застосування антиінгібіторного коагуляційного комплексу у клінічному спостереженні хворого угематологічному відділенні Комунального підприємства «Полтавська обласна клінічна лікарня ім. М.В. Скліфосовського Полтавської обласної ради».

\section{Клінічний випадок}

Пацієнт М., 52 роки. У дитинстві встановлено діагноз «гемофілія А, спадкова недостатність ФЗК VIII, тяжка форма (рівень ФЗК VIII $<1 \%)$, ускладнена гемофілічною поліартропатією ліктьових, колінних, гомілково-ступневих та лівого променево-зап'ястного суглобів». Хворий отримував лікування кріопреципітатом та замісну терапію концентратами ФЗК VIII за потребою.

У грудні 2014 р. у хворого спонтанно розвинувся гострий гемартроз правого колінного суглоба. На 3-тю добу від початку крововиливу хворого госпіталізовано у гематологічне відділення 
Полтавської обласної клінічної лікарні зі скаргами на сильний розпираючий біль із вираженим обмеженням активних та пасивних рухів у правому колінному суглобі, збільшення останнього у розмірах, підвищення температури тіла до $37,2^{\circ} \mathrm{C}$, загальну слабкість.

При об'єктивному огляді хворий у свідомості, знаходиться у вимушеному положенні у ліжку через виражений больовий синдром. Правий колінний суглоб збільшений у розмірах, гарячий на дотик, шкіра над нам гіперемована. Загальний стан пацієнта стабільний, шкіра та видимі слизові оболонки блідо-рожеві, набряків немає. Лівий колінний суглоб, ліктьові, гомілково-ступневі та лівий променево-зап'ястний суглоби деформовані, мають місце постгемартрозні анкілози.

У гемограмі усі показники у межах норми:еритроцити 4,93·1012/л, гемоглобін 143 г/л, тромбоцити 307·109/л, лейкоцити 5,34.10\%/л, еозинофіли 2\%, базофіли 0\%, паличкоядерні нейтрофіли 2\%, сегментоядерні нейтрофіли $71 \%$, лімфоцити $20 \%$, моноцити 5\%, швидкість осідання еритроцитів 18 мм/год. Виявлено значно подовжений час згортання за Лі - Уайтом: початок згортання через 15 хв, кінець 25 хв. У коагулограмі виявлено подовження активованого часткового тромбопластинового часу до 67 с, за нормальних показників рівня фібриногену 3,6 г/л, протромбінового часу 9,8 с, міжнародного нормалізованого відношення 0,84. Спостерігали зниження рівня ФЗК VIII $<0,4 \mathrm{MO} /$ дл.

Праву нижню кінцівку іммобілізовано у припіднятому положенні та тричі прикладено лід із використанням мішка для льоду на 15 хв з інтервалом 30 хв. Розпочато замісну терапію плазмовим концентратом ФЗК VIII у дозі 1500 МО внутрішньовенно струминно через 12 год. 3 метою знеболення та досягнення протизапального ефекту призначено парацетамол у дозі 1000 мг кожні 4 год. Проте на 2-гу добу госпіталізації бажаного клінічного ефекту не досягнуто. Дозу концентрату фактора VIII підвищено вдвічі. Водночас до лікування додано дексаметазон у дозі 8 мг внутрішньовенно струминно, що дозволило зменшити вираженість больового синдрому. Проте явища гострого гемартрозу у пацієнта зберігалися протягом декількох тижнів. Саме тоді вперше діагностовано наявність інгібітора до ФЗК VIII, активність якого виявилася високою і становила 47,1 БО/мл. Геморагічні епізоди, в основному гемартрози, відмічали у хворого до 5-6 разів на рік, кожен епізод потребував госпіталізації, введення високих доз концентратів фактора VIII у комбінації з глюкокортикостероїдами.

Через 2 роки, у липні 2016 р., під час чергового лікування гострого гемартрозу лівого ліктьового суглоба хворому вперше призначено антиінгібіторний антикоагулянтний комплекс ФЗК II, VII, IX, X у дозі $6500 \mathrm{MO}$ (70 МО/кг) внутрішньовенно струминно через 12 год протягом 3 днів. Клінічний ефект, а саме значне зменшення вираженості больового синдрому, нормалізація розмірів суглоба та відновлення активних та пасивних рухів у об'ємі, що відповідав такому до крововиливу, відмічали вже наступного дня після введення препарату.

У подальшому, в період 2016-2019 рр., хворий отримував терапію антиінгібіторним антикоагулянтним комплексом за вимогою. Впродовж зазначеного періоду у пацієнта спостерігали спонтанні геморагічні епізоди у вигляді гемартрозів 3-4 рази на рік. Застосування препарату приводило до швидкого усунення клінічних проявів крововиливів у таргетні суглоби.

У грудні 2019 р. при контрольному дослідженні крові зберігалася висока активність інгібітора фактора VIII 23 БО/мл. Хворому надано чіткі рекомендації щодо профілактичного застосування антиінгібіторного коагуляційного комплексу ФЗК II, VII, IX, X у дозі 80 МО/кг 3 рази на тиждень. Це дозволило попередити розвиток геморагічних епізодів.

\section{За підтримки ТОВ «Такеда Україна»} VV-MEDMAT-43973

\section{Список використаної літератури/References:}

1. Giangrande P.L.F., Hermans C., O'Mahony B. et al. (2018) European principles of inhibitor management in patients with haemophilia. Orphanet. J. Rare Dis., 13: 66. https://doi. org/10.1186/s13023-018-0800-z

2. Srivastava A., Santagostino E., Dougall A. et al. (2020) WFH Guidelines for the Management of Hemophilia, 3rd ed. Haemophilia, 26 (Suppl. 6): 1-158. doi: 10.1111/hae.14046

3. Vydyborets S.V., Derpak Yu.Yu., Popovich Yu.Yu. (2018) Hemophilia. Family medicine, 6(80): 61-66. (In Ukr.).

4. Stasyshyn 0.V. (2021) Individualized approach to factor therapy of hemophilia: possibilities of modern technologies. Ukr. Med. J., 1(141): 1. DOl: 10.32471/umj.1680-3051.141.197253 (In Ukr.).

5. Franchini M., Coppola A., Tagliaferri A. et al. (2013) FElBA versus NovoSeven in Hemophilia Patients with Inhibitors. Semin. Thromb. Hemost., 39: 772-778. D0I http://dx.doi. org/10.1055/s-0033-1354425

6. Antunes S.V., Tangada S., Stasyshyn 0. et al. (2014) Randomized comparison of prophylaxis and on-demand regimens with FEIBA NF in the treatment of haemophilia $A$ and $B$ with inhibitors. Haemophilia, 20: 65-72. Dol: 10.1111/hae.12246

\section{Prevention of bleeding in patients with hemophilia}

I.M. Skrypnyk ${ }^{1}$, G.S. Maslova', Iu.O. Gusachenko' ${ }^{2}$, T.V. Lymanets ${ }^{1,2}$

'Ukrainian Medical Stomatological Academy, Poltava, Ukraine ${ }^{2}$ Municipal Enterprise «Poltava Regional Clinical Hospital named after M.V. Sklifosovsky of Poltava regional Council», Poltava, Ukraine

Abstract. Management of patients with severe hemophilia A and $B$ remains a complex problem in clinical medicine due to the high frequency of antibodies against deficient factors. The solution may be the use of drugs with a shunt mechanism of action, namely activated eptacog alfa ( $\mathrm{rFVlla}$ ) and antiinhibitory coagulation complex of blood coagulation factors II, VII, IX, X. The effectiveness of antiinhibitory coagulation complex has been proven by international randomized clinical trials - about $80 \%$. Its significant advantage is a long half-lifeup to 8-12 hours. From the modern point of view, the principles of application of the antiinhibitory coagulation complex for the purpose of prevention of bleeding episodes are important. According to the results of international randomized clinical trials, its prophylactic use is maximum effective, which involves the introduction of a dose of 80-85 IU/kg 3 times a week.

Key words: bleeding prevention, inhibitory form of hemophilia, shunting mechanism of action, antiinhibitory coagulation complex.

\footnotetext{
Відомості про авторів:

Скрипник Ігор Миколайович — заслужений діяч науки і техніки України, доктор медичних наук, професор кафедри внутрішньої медицини № 1 Української медичної стоматологічної академії, Полтава, Україна.

Маслова Ганна Сергіївна — кандидат медичних наук, доцент, завідувач кафедри внутрішньої медицини № 1 Української медичної стоматологічної академії, Полтава, Україна.

Гусаченко Юлія Олександрівна — завідувач гематологічного відділення КП «Полтавська обласна клінічна лікарня ім. М.В. Скліфосовського ПОР», Полтава, Україна.

Лиманець Тетяна Володимирівна — кандидат медичних наук, асистент кафедри внутрішньої медицини № 1 Української медичної стоматологічної академії, лікар-гематолог гематологічного відділення КП «Полтавська обласна клінічна лікарня ім. М.В. Скліфосовського ПОР», Полтава, Україна. Адреса для кореспонденції:

Лиманець Тетяна Володимирівна

36011, Полтава, вул. Шевченка, 23

E-mail: tlymanets@gmail.com
}

\section{Information about the authors:}

Skrypnyk Igor M. - Honored Worker of Science and Technology of Ukraine, Doctor of Medical Sciences, Professor of the Department of Internal Medicine № 1 of the Ukrainian Medical Stomatological Academy, Poltava, Ukraine.

Maslova Ganna S. — Candidate of Medical Sciences, Associate Professor, Head of the Department of Internal Medicine № 1 of the Ukrainian Medical Stomatological Academy, Poltava, Ukraine.

Gusachenko luliia 0. - Head of Hematology Department of ME «Poltava Regional Clinical Hospital named after M.V. Sklifosovsky PRC", Poltava, Ukraine.

Lymanets Tetiana V. — Candidate of Medical Sciences, assistant of the Department of Internal Medicine № 1 of the Ukrainian Medical Stomatological Academy, hematologist of Hematology department of ME «Poltava Regional Clinical Hospital named after M.V. Sklifosovsky PRC», Poltava, Ukraine. Address for correspondence:

Tetiana Lymanets

36011, Poltava, Shevchenko str., 23

E-mail: tlymanets@gmail.com 